\title{
THE UNORIGINALITY OF AFRICAN SOCIO-POLITICAL THEORIES: A JUSTIFICATION
}

\author{
PAUL CHINENYE IREGBENU \\ E-mail:iregbenu2002@yahoo.com
}

\section{INTRODUCTION}

The cradle of colonialism in Africa was at the Berlin Conference of 1884-85, which saw to the partitioning of Africa among six European nations. The African experience shows that colonialism created for the continent a socio-political situation from which she needed emancipation. Thus, as some Africans began having access to western education, they became armed with the weapons of pen and paper and in turn, sought to extricate their fatherland from the sway of colonialism. This gave rise to African socio-political theories propounded by the likes of Kwame Nkrumah, Léopold Sédar Senghor, Julius Kambarage Nyerere, Nnamdi Azikiwe and Obafemi Awolowo. This paper sets out to examine the originality of their theories. It is important to note here that originality referred to, is understood as creativity which entails one being the initiator of an idea or a plan. Thus, it follows that to examine the originality of the African socio-political theorists is synonymous to checking whether they are the actual initiators of these theories or whether they adopted them from someone else. Finding this out is the primary objective of this study. To do this, a lucid presentation of these theories is apropos.

\section{PHILOSOPHICAL CONSCIENCISM}

Kwame Nkrumah (1909-1972) began his move for the emancipation of Africa from the throttlehold of colonialism by criticizing capitalism. "Capitalism", according to him, "is a refined form of feudalism, which in turn is a refined form of slavery." ${ }^{1} \mathrm{He}$ posits that capitalism is alien to the traditional African society. The African society, for Nkrumah, has three segments: the traditional, the Western, and the Islamic. These co-exist uneasily; the principles animating them are often in conflict with one another. The traditional segment illustrates how the principles which inform capitalism are in conflict with the 
socialist egalitarianism of the traditional African society. ${ }^{2}$ The Western and Islamic segments, as Nkrumah opines, if they must be rightfully seen, should be accommodated only as experiences of the traditional African society. A failure to do this would see African society being racked up by the most malignant schizophrenia. ${ }^{3}$ Consequently, one must assume a purposeful attitude towards the Western and Islamic experiences. This purposeful attitude must be guided by thought, "for practice without thought is blind." ${ }^{4}$ Hence Nkrumah says,

What is called for as a first step is a body of a connected thought which will determine the general nature of action in unifying the society which we have inherited, this unification to take account, at all times, of the elevated ideals underlying the traditional African society. ${ }^{5}$

Further reiterating, such a social revolution must be marked by an intellectual revolution ("a revolution in which our thinking and philosophy are directed towards the redemption of our society" ). The philosophy that must stand behind this social revolution, for Nkrumah, is the Philosophical Consciencism, which he explains thus:

Consciencism is the map in intellectual terms of the disposition of forces, which will enable African society to digest the Western, the Islamic and Euro-Christian elements in Africa, and develop them in such a way that they fit into the African personality. The African personality is itself defined by the cluster of humanist principles which underlie the traditional society. Philosophical consciencism is that philosophical standpoint which, taking its start from the present content of the African conscience, indicates the way in which progress is forged out of the conflict in that conscience. ${ }^{7}$

The basis of this philosophical consciencism is materialism whose minimum assertion is the absolute and independent existence of matter. Matter itself is a plenum of forces which are in antithesis to one another. ${ }^{8}$ Another assertion here is that matter has the power of self- 
motion. ${ }^{9}$ Matter being capable of self-motion is to be understood in the sense of change of relation, and in the sense of change of property but not as inert in the sense of the philosophers. ${ }^{10}$ To the extent of the twofold assertions, philosophical consciencism is deeply materialistic. It is pertinent to note that philosophical consciencism being materialistic does not imply the affirmation of sole reality of matter. If it does, then it means that philosophical consciencism would hold spirit as a category of being, and the phenomenon of consciousness, like that of self-consciousness would also be held as an aspect of matter. ${ }^{11}$ Hence, it would be atheistic. Philosophical consciencism, even though deeply rooted in materialism is not necessarily atheistic. ${ }^{12}$ Atheism brews up when one affirms matter as the solely existing reality.

Nkrumah believes that we (Africans \& humans in general) are made up of body and mind. As such, in his philosophical consciencism the interaction of mind and body is accepted as a fact. ${ }^{13}$ "The philosophical perplexity which darkens this interaction is removed by the demonstration of the possibility of categorial conversion." 14 By categorial conversion, one does not mean Descartes' parallelism (perhaps then Descartes' solution to the mind-body problem was referred to as parallelism unlike now it is referred to as interactionism) a panacea for the mind-body problem. Descartes "instituted parallel occurrences, and thus explained pain as that grief which the soul felt at the damage to its body." tends to show that "if the mind could be said to grieve in this way, then one might say that the body could affect the mind. But not so necessarily, for according to Descartes, the body does not affect the mind, but the mind commiserates with the body." 16 Philosophical consciencism has no room for a mere parallelism but retains the two categories of mind and body that interacts by way of categorical conversion. ${ }^{17}$

Philosophical consciencism, as we must have observed, does not assert the sole reality of matter but asserts the priority of matter. It also claims the reality of categorial conversion. This categorial conversion entails a conversion from one category to another category produced by a dialectical process; a conversion that represents a variation in the mass of its initial matter, which involves a loss of mass. ${ }^{18}$ 
"It is this reality of categorial conversion which prompts philosophical consciencism to assert not the sole reality of matter, but its primary reality." ${ }^{19}$

It follows that in philosophical consciencism, "matter is capable of dialectic change, for if natural properties are nothing but surrogates of quantitative dispositions of matter, then since natural properties change, matter must change in quantitative disposition. ${ }^{20}$ For Nkrumah, matter must have the power of self-motion original to it. Without self-motion, dialectical change ${ }^{21}$ would be impossible.

Thought without practice is empty ${ }^{22}$. This was not the case for philosophical consciencism of Kwame Nkrumah since it thus has areas of practical significance; "it so restricts itself to the reflection of the objective unfolding of matter, it also establishes a direct connection between knowledge and action." ${ }^{23}$ The question now is, can one conceive the connection of knowledge and action by philosophical consciencism a purely mechanistic one, or whether it makes it susceptible of ethical influence and comment? ? $^{24}$

The above question was answered when Nkrumah says, ...it is evident at least that philosophical consciencism cannot issue in a closed set of ethical rules, a set of rules which must apply in any society and at any time. Philosophical consciencism is incapable of this because it is itself based upon a view of matter, as caught in the grip of an inexorable dialectical evolution. ${ }^{25}$

As a result, ethical rules championed by philosophical consciencism would not be permanent but would depend "on the stage reached in the historical evolution of a society, so however those cardinal principles of egalitarianism are conserved." ${ }^{26}$ Explaining further, Nkrumah says,

A society does not change its ethics by merely changing its rules. To alter its ethics, its principles must be different. Thus, if a capitalist society can become a socialist society, then a capitalist society will have changed its ethics. Any change of ethics 
constitutes a revolutionary change. ${ }^{27}$

The cardinal ethical principle of philosophical consciencism is to consider each man as an end in himself and not merely as a means. This principle looks similar to Kant's categorical imperative but varied in that Kant's principle is the dictate of reason whereas Nkrumah's is the dictate of materialism. $^{28}$

Egalitarianism consists in the ethics philosophical consciencism issues, which materialism also issues on the social plane to an extent. As a social reflection of materialism, egalitarianism is based on the monistic thesis of materialism which holds that matter is one even in its different manifestations. $^{29}$ If matter is one, it follows that there is a route connecting any two manifestations of matter. This route could pass through the third form and is not direct or unilinear but dialectical. ${ }^{30}$ Going further on the source of egalitarianism, Nkrumah states:

It is the basic unity of matter despite its varying manifestations, which gives rise to egalitarianism. Basically, man is one, for all men have the same basis and arise from the same basis and a rise from the same evolution according to materialism. This is the objective ground of egalitarianism. ${ }^{31}$

In its political aspect, philosophical consciencism is faced with the realities of colonialism, imperialism, neo-colonialism ("negative action playing possum,"32), disunity and lack of advancement. In colonial situation, negative action outweighs positive action. ${ }^{33}$ For independence to be won, it is necessary that positive action should overwhelm negative action. Negative action represents the sum of forces tending to prolong colonial subjugation and exploitation, while positive action represents the sum of those forces seeking social justice in terms of destroying oligarchic exploitation and oppression. Positive action is revolutionary and negative is reactionary. ${ }^{34}$ For positive action to overwhelm the negative action, it needs to be backed by an ideology, "an ideology which vitalizing it and operating through a mass party shall equip it with a regenerative concept of the world and life, forge for it a strong continuing link with our past and offer to it an 
assured bond with our future." ${ }^{35}$ That ideology is philosophical consciencism.

\section{AWOLOWO'S SOCIALISM}

Obafemi Awolowo (1909-1987) was a convinced, uncompromising and consummate advocate of socialism. Little wonder, in his political life he was consistently on the critical side in a capitalist state. To establish his philosophy, socialism, Awolowo first makes a distinction between the primary aim and ultimate purpose of a state. While the primary aim is to maintain internal order and prevent eternal aggression, the ultimate purpose is to enable the citizens of a state to enjoy the fruits of their labour, and to live full and happy life, including the enjoyment of the fundamental human rights. ${ }^{36}$ In man's bid to attain the ultimate purpose of a state, he has adopted two well-known economic systems, namely the capitalist and socialist system. Analyzing capitalism, Awolowo acknowledges some achievements credited to it. He however, points out that capitalism has done more harm than good to humanity. "Its four postulates [of private property, choice, equality and egoistic altruism] are false and untenable." ${ }^{37}$ The scenario provided by capitalism is one where one capitalist succeeds or survives with probably more than ten thousands going under completely, never to rise again. ${ }^{38}$ Thus, capitalism is evil and would suffer the same fate as slavery and feudalism. ${ }^{39}$

It is important to note that the socialism advocated by Awolowo differs from that of Marx and Engels since these latter saw socialism as a stage between capitalism and communism. The principle of Marx's and Engels' socialism is from each according to his ability and to each according to his deeds and it is marked by the dictatorship of the proletariat. ${ }^{40}$ The capitalist having suppressed the proletariat in the capitalist system, will be suppressed by the proletariat in the socialist system. This stage in the dialectical process of the evolution of society will be superseded by communism (stateless society where the principle would be from each according to his ability, to each according to his needs) which is a stage of social perfection. ${ }^{41}$ Awolowo repudiates the brand of socialism propounded by Marx and Engels due to the presence of the dictatorship of the proletariat in it. Also, he thinks that the idea of a stateless society is unrealistic for never will there be a time 
when man will not need the state. ${ }^{42}$ Having made this distinction, Awolowo outlines what the objectives of socialism are:

- The abolition of rent, dividend or profit, interest and inheritance;

- The legal elimination of renter class;

- The recognition that all the able-bodied citizens of the state are workers or labourers of various gradations and skills. And all ablebodied citizens who work or render service to the state are entitled to remuneration only in form of salaries or wages of various scales. Every money or wages received must be worked for and earned. Hence money collected from rents by landlords or dividends from shares by shareholders are unearned and therefore unfounded. ${ }^{43}$

To enthrone the kind of socialism he wants, Awolowo admits that man's wants are unlimited but his needs are limited and can be regulated by legislation. ${ }^{44}$ Legislation is to distinguish between what man needs and what he wanted. As it does this, it ought to guarantee for all citizens a minimum standard of living while at the same time a maximum standard should be set which no one should be allowed to exceed in a society. The gap perceived between the minimum and the maximum should be regulated so as to ensure the least possible abrasion among entire inhabitants. All the means of production should be vested in the state; those already in the hands of individual citizens should be sequestered by the state and the owners fairly remunerated. ${ }^{45}$

A look at the socialism advocated for by Awolowo reveals a dispossession of the individual of his freedom. A demurral which Awolowo replies "that it is for the good of the individual himself that his freedom be curtailed by the state. ${ }^{, 46}$ Awolowo sees the state as family, where the father determines what is good to be done by the members of the family. Also, Awolowo's socialism is not brought about by the use of force. For Awolowo, the use of force is not necessary "so long as the objective and the method of approach are good, constructive and beneficial to all. ${ }^{, 47}$ It is only when these criteria are satisfied that the actual change from capitalism to socialism can be realized. But if force must be used then it must be according to the working of the universal 
law of justice. This is the consequence of the actions of some selfish individuals who resolved to foil the introduction of what will be beneficial to all the citizens. In this case, "violence may be the only effective means of bringing about the change, according to the universal law of justice which works for the elimination of evil." ${ }^{48}$ Another fact about Awolowo's socialism which has been criticized is that it discourages private property and individual enterprise and this, slows the progress of the socialist economy. ${ }^{49}$ Profit motif or individual enterprise is necessary for economic growth. To this, Awolowo argues that the term profit motif is simply an euphemistic term for the vices of naked greed and selfishness. ${ }^{50}$ Similarly, Awolowo's socialism is very much in the spirit of Christianity and not an atheistic system which excludes religion. Furthermore, Awolowo's socialism has a universal application like normative science (ethics).

Finally, "it is Awolowo's conviction that capitalism is an evil system which will sooner or later give way to socialism." ${ }^{, 51}$ The apparent conquest of evil and its resistance to good is only ephemeral; it will eventually flop, giving way for good. "This is the law of nature, the universal law of justice which works for the elimination of evil and the triumph of good." 52

\section{LEOPOLD SENGHOR'S NÉGRITUDE}

Senghor's négritude arose from the background of dehumanization. It is first and foremost a literary expression that gave rise to an influential philosophical current. Négritude as a movement started in the 1940s. It was opposed to the French assimilation policy which championed the superiority of the European culture. Pertinent to note, it was a heroic effort to re-discover or rediscover the spirit of Africa. In fact, négritude aims at reasserting and reviving through literature, African values, identity and authenticity. For Oguejiofor, "it is an attempt to project the African specificity, Africanité." ${ }^{53}$ Senghor seeks to establish the difference between the African and the rest of human beings, even though the constant point of reference was the western man. ${ }^{54}$ The reason for the project of Négritude, though undeclared, is "the felt need to counter the indignity of colonialism and the African condition." ${ }^{, 55}$ More so,

It was to serve as a counter point by presenting 
something different, something somehow alien to the West, which will serve as the special characteristic for the African existence, especially as distinguished from other races of mankind. Négritude is an effort to counter the pride and the psychological domination of the Western culture. ${ }^{56}$

Senghor believes strongly that the African's colonial past has given him a load of inferiority complex that can only be thrown overboard by the assertion of the African's values. ${ }^{57}$ Senghor's négritude is thus "a weapon of defense and inspiration. ${ }^{, 58}$ Apparently the best strategy in this project is self- affirmation as a counter to centuries of inferiority complex. Such self-affirmation is, for Senghor, the most important factor in the common psyche of a people, a people that must be defined by their uniqueness. Short of this uniqueness, short of their unique message, which only they can proclaim, a people turn to a museum piece. ${ }^{59}$ According to Oguejiofor:

Senghor defends the difference between the European and African apprehension of being. Before an object, the European distances himself, he makes it other, and as it were, freezes it out of time and space. He kills the object to make use of it. It could be said that the European is analytical and practical, and it is this that is designated as domesticating or dehumanizing nature. The African, on the other hand, does not distance himself, nor does he analyse, he feels the object. He is thus nearer to what Senghor describes as "the stimulus of the object", at one with its rhythm, a sense of rhythm which one of the specific characteristics of the African. ${ }^{60}$

This African's apprehension of the object naturally underlies his relationship with fellow humans. The African society, as Senghor rightly observes, is essentially based on human relationship. The African abandons the 'I' to identify with the 'Thou. ${ }^{, 61}$

As Oguejiofor notes, he (the African) is tailor-made for 
communal life, living as it were in symbiosis. ${ }^{62}$ This is because he does not see mere outward appearance in objects or in the other. He apprehends the reality, the cosmic life-force which lies behind the objects and gives rise to emotion when it imposes itself on consciousness. It is in this sense that emotion, rather than representing a failure of consciousness becomes ascension to a higher level of consciousness on account of the unity between the object and the subject. ${ }^{63}$

From the foregoing, one could interpret that Senghor means rationality is a special characteristic of the European, whereas emotion is that of the African. But if the quest for difference goes as far as affirming this, then there would be no answer to his critics. The truth is that Senghor uses emotion to distinguish what he calls African and European reasoning. ${ }^{64}$ Fundamentally, reason is one, Senghor says, in the sense that its quest is always the apprehension of reality. The difference lies in the operation of reason. Nonetheless, Senghor insists on this difference. The African reason is marked by reason-by-embrace, which shares more the nature of the logos than ratio. ${ }^{65}$

\section{JULIUS NYERERE'S UJAMAA}

Ujamaa as a concept constitutes the basis of Julius Kambarage Nyerere's social and economic development policies in Tanzania after it gained independence from Britain in 1961. It possesses the meaning of oneness; uniting with one's country men as one extended family. In short, Ujamaa is a Swahili word for familyhood. Ujamaa is distinguished by several key characteristics, namely that a person becomes a person via the community.

Nyerere sets out his Ujamaa policy in the Arusha Declaration of 5 February, 1967; this was Nyerere's development blueprint. In it, Nyerere points out the need for an African model of development and that constitutes the foundation of African socialism. President Nyerere of Tanzania in his discourse of Ujamaa said that Ujamaa is

based on the assumption of human equality, on the belief that it is wrong for one to dominate or exploit another, and on the knowledge that every individual 
hopes to live in a society as a free [person] able to lead a decent life, in condition of peace with his [or her] neighbor. ${ }^{66}$

For Nyerere, Ujamaa is above all human centered, concerned primarily with the well-being, happiness and development of the human person. "And the assumption is that the conditions for such well-being, happiness and development are best achieved in a context of shared social wealth." 67

Talking of wealth, in Ujamaa, the production of wealth is accounted by the land given by God, the tools and labour. It is taken for granted that every member of the society contributes his or her own share of efforts towards the production of wealth. The idea of wealth meant here is not wealth for wealth's sake as opposed to the well-being for all. The creation of wealth is a good thing, according to Nyerere, and it is something Africans shall have to increase. However, it (the creation of wealth) ceases to be good the moment wealth ceases to serve man and begins to be served by man.

Also, Ujamaa reiterates self-reliance in the building, strengthening and controlling of the economy of the African community. Nyerere has said self-reliance in Ujamaa means "first and foremost...that for our development we have to depend upon ourselves and our own resources." ${ }^{68}$ The assumption here is that we must seize and maintain the initiative in all that is ours, and that we must harness our resources and put them to the best possible use in the service of the community. This, he says does not mean denying all assistance from or work with others but of controlling policy and shouldering the essential responsibility for our own future.

Self-reliance espoused here tends to re-iterate Ujamaa's belief that all men are equal and possess the freedom of expression. Closely related to this concept of self-reliance and the responsibility it requires is the respect for the dignity and obligation of work. "To respect work is to appreciate its value, reject its exploitation and engage in it cooperatively for the common good of the community." Nyerere is of the opinion that in the traditional African society, everyone was a worker. By worker, Nyerere refers to a non-loiterer or non-idler. In fact, Nyerere would suggest that a visitor to an African home, having stayed up to two days in that home, is given a 
hoe to cultivate in the farm of the person visited. This portrays the relevance of the concept of work to Nyerere's Ujamaa philosophy. In addition, inherent in Ujamaa is the emphasis on and the obligation of generosity especially to the poor and vulnerable.

Finally, for Nyerere, African socialism contrasts the European socialism in that the latter is as a result of conflicting classes(the capitalist bourgeoisies versus the industrial proletariats) and in the society, whereas the former is not as a result of conflicting classes in the society. The basis for African socialism is the extended family. All men are to be seen as members of this extended family. There is no class war where a class of men is perceived as brethren and another as enemy to be exterminated. In fact, this African proverb: A man cannot sit alone to plan for prosperity, holds sway.

\section{NNAMDI AZIKWE'S NEO-WELFARISM}

Nnamdi Azikiwe examines the political systems of capitalism, socialism and welfarism and finds these systems wanting respectively. However, none of them, in Azikiwe's view, is comprehensively bad without some good elements. Azikiwe then, following the principles of eclecticism and pragmatism, tries a harmonization of the good elements in capitalism, socialism and welfarism. The result of this 'harmonization of opposites' is what he calls Neo-Welfarism. Neo-welfarism as an ideology for Azikiwe, is

...a vernal and dynamic interpretation of
welfarism and its synchronization into a social
matrix of the last elements in the universally
recognized ideologies of capitalism, socialism
and welfarism.... Simpliciter, neo-welfarism
embraces belief in private enterprise, reinforced
by state participation in the private sector and
state collaboration in management technology
for completely and efficiently administering on a
profitable basis statutory corporations and
parastatals, commercial enterprises including
government- controlled and government-
sponsored companies.

Neo-welfarism as a political philosophy is eclectic and pragmatic. As eclectic, it incorporates ideas selected from the systems; hence a composite system of thought. It does not modify but blends 
opposite views. It is not syncretic since it does not attempt to reconcile the irreconcilables. As pragmatic, it works to the advantage of the many, and does not speculate to the disadvantage of the many when assessed by its practical results. $^{71}$

Azikiwe via his philosophy sought a society that "will not be capitalist; it will not be socialist, and it will not be welfarist. Rather, it will be a harmony of opposites atop of 'our external family system' to further the frontiers of state responsibility for the welfare of all its citizens." ${ }^{, 72} \mathrm{~A}$ neo-welfarist state by combining the good elements of capitalism, socialism and welfarism will avert the evils in these systems. Thus, in Neo-Welfarism, the free competition of capitalism, which acts as an incentive to efficiency, is moderated by socialism's emphasis on communal interest and the welfare of all as seen in welfarism.

Most importantly, for Azikiwe, neo-welfarism is based on the traditional African society. To ensure stability of the state there shall be checks and balance. Thus, the neo-welfarist government should be made up of four arms: the Electorate, the Judiciary, the Executive, and the Legislative. $^{73}$

In terms of social services, a neo-welfarist government shall aim at fair and equitable distribution of the country's goods among the citizens and avoid the situation whereby some citizens are extremely affluent while others are in abject penury. The state provides essential social services, the citizens are obliged to contribute 'a fair computed tax' to the state. $^{74}$

After the study of three foreign ideologies - capitalism, socialism, and welfarism -Azikiwe decided that the best option is neo-welfarism. This involves adapting modern ideologies of alien extraction to the indigenous ideology, which had enabled our forebears to conquer the elements.

\section{ARGUMENTS TO JUSTIFY THE PROPOSITION THAT THE AFRICAN SOCIO-POLITICAL THEORIES ARE NOT ORIGINAL}

The African socio-political theorists are essentially politicians. Thus, Oguejiofor asserts that "their main interest and preoccupation were hardcore politics and not philosophy. Consequently, they were 
unhindered by any special quest for a specific African philosophy." ${ }^{, 75}$ This implies that they are not so much interested with developing new philosophical systems as such; they mostly use already established systems, with little amendments, to support their political motives.

More still, given the socio-political situation of Africa (colonialism), Oguejiofor posits that "their major aim was not to pass as philosophers, but to seek for the political and economic liberation of the continent." ${ }^{, 76}$ As a result, he says: "These thinkers were not averse to borrowing foreign ideologies and giving them an African slant, or proclaiming that these were supported by the original African tradition." ${ }^{, 77}$ This gives credence to the fact that the African socio-political theorists borrowed their ideas from foreign ideologies, thus, these ideas are not original to them.

In addition, Nkrumah adopting matter as a fundamental unity and primary element underlying the diversity of things followed an already existing trend started by the ancient Greek philosophers such as Thales, Anaximander, Anaximenes, Heraclitus etc., who are preoccupied with finding the "primary stuff of which all things are made, and which explains the continuity in changes and the underlining unity in the plurality of things. ${ }^{78}$ Also, Nkrumah's notion of materialism, despite its contending for the primary reality of matter, looks akin to that of Karl Marx. As a result it follows logically that Nkrumah's theory of materialism as contained in his Consciencism is not original to him.

Equally important, Nkrumah's idea of tension, conflict, or struggle being condition for development, can be traced to Marxian dialectical materialism, which in turn can be traced to Hegel's dialectics. Thus, Hegel affirms that "contradictions, tensions, ironies, paradoxes, oppositions...are at the heart of all thought and even reality itself." ${ }^{, 79}$ This presupposes that idea of tension as the law of progress is simply not original to him.

Also, Senghor's idea that the African reasons emotionally, while the European reasons rationally, is adopted from the writings of many European philosophers like Hegel, and anthropologists like Levy Bruhl, who try to show that Africans are primitive by designating them as sentimental thinkers. Thus, this idea of Senghor is not original to him. In addition, as discovered, Aimé Césaire, Léopold Sédar 
Senghor and Léon-Gontran Damas are the three Francophone black intellectuals who propagate the movement called Négritude. Therefore, one can say that Senghor is not the initiator of La Négritude but he made veritable contributions towards its advancement.

Furthermore, Nyerere's idea of dignity in labour, and the involvement of the rulers in labour are traceable to Karl Marx's theory of alienation of labour. Marx in this theory affirms that there is dignity in labour and also, argues against the oppression of the workers by the rulers. Similarly, Nyerere's Ujamaa is based on equality which also marks the base of Marxian socialism. Thus, such an idea is not original to him; he just appropriated Marx's idea.

Also, Awolowo's socialism, though he tries to differentiate it from that of Engels and Marx, is grossly Marxian. He criticizes capitalism just like Marx and recommends socialism as the best system just like Marx. Also, the terms, capitalism and socialism were used principally by Marx. Thus, it follows logically that Awolowo's theory is not original to him.

In addition, Azikiwe's idea of the four arms of government - the Electorate, the Judiciary, the Executive, and the Legislative - is borrowed from John Locke, who discusses these arms of government at length in his political philosophy. Thus, Azikiwe's idea of Neo-welfarism, which was a harmonization of three foreign ideologies, is not original to him.

At this juncture, it is pertinent to note that most of the African socio-political theorists studied abroad; thus, they internalized a lot of foreign ideologies which are evident in their theories. Thus, Azikiwe writes: "During our student days, our minds were pliable and impressionable. Our lives were therefore conditioned by the behaviour patterns of our intellectual mentors." ${ }^{, 80} \mathrm{He}$ also affirms that they are "evangelists of the old and new isms." 81

\section{CONCLUSION}

To conclude, subscribing to Oguejiofor's brutal assessment of the originality of African political theories would be apposite for a work as this, he avers that these "African political philosophers had either little or nothing really African in their specific political theories." ${ }^{, 82}$ As could be seen from the foregoing, arguments are rendered to defend 
the adopted position that African socio-political theories are not original to their proponents. Their theories were mainly foreign ideologies. However, this does not in any way discredit their contributions. Therefore, since these theorists use concepts in a way that have not been done before, one can to a reasonable extent, credit them with originality in their contribution to learning and their being able to modify these foreign theories and applying them to the African socio-political situation. 


\section{END NOTES}

${ }^{1}$ J. Omoregbe, Knowing Philosophy, (Lagos: Joja Publishers Limited, 1990), p.31

${ }^{2}$ K. Nkrumah, Consciencism- Philosophy and Ideology for Decolonisation, Retrieved from http://consciencism.wordpress.com/history/consciencism-philosophy-andideology-for-decolonisation/ (Access 6/3/2014)

${ }^{3}$ Ibid

${ }^{4}$ Ibid.

${ }^{5}$ Ibid.

${ }^{6}$ Ibid.

${ }^{7}$ Ibid.

${ }^{8}$ Ibid.

${ }^{9}$ Ibid.

${ }^{10}$ Ibid.

${ }^{11}$ Ibid.

${ }^{12}$ Ibid.

${ }^{13}$ Ibid.

${ }^{14}$ Ibid.

${ }^{15}$ Ibid.

${ }^{16}$ Ibid.

${ }^{17}$ Ibid.

${ }^{18}$ Ibid.

${ }^{19}$ Ibid.

${ }^{20}$ Ibid.

${ }^{21}$ By dialectical change, Nkrumah means the "emergence of a third factor of a higher logical type from the tension between two factors or two sets of factors of a lower logical type. Matter belongs to one logical type, properties and qualities of a matter to a higher logical type, properties of properties to an even highest logical type." (Ibid) ${ }^{22}$ Ibid.

${ }^{23}$ Ibid.

${ }^{24}$ Ibid.

${ }^{25}$ Ibid.

${ }^{26}$ Ibid.

${ }^{27}$ Ibid.

${ }^{28}$ Ibid.

${ }^{29}$ Ibid.

${ }^{30}$ Ibid.

${ }^{31}$ Ibid.

${ }^{32}$ Ibid.

${ }^{33}$ Ibid.

${ }^{34}$ Ibid. 
${ }^{35}$ Ibid.

${ }^{36}$ O. Awolowo, People's Republic,(Ibadan: Oxford University Press, 1968), p.119

${ }^{37}$ J. Omoregbe, Op. Cit., p. 53

${ }^{38}$ O. Awolowo, Loc. Cit., p.166

${ }^{39}$ J. Omoregbe, Loc. Cit., p. 55

${ }^{40}$ Ibid., p. 56

${ }^{41}$ Ibid.

${ }^{42}$ Ibid.

${ }^{43}$ Ibid.

${ }^{44}$ Ibid., p. 57

${ }^{45}$ Ibid.

${ }^{46}$ Ibid.

${ }^{47}$ Ibid.

${ }^{48}$ Ibid., p. 58

${ }^{49}$ Ibid.

${ }^{50}$ Ibid.

${ }^{51}$ Ibid., p. 60

${ }^{52}$ Ibid.

${ }^{53}$ J. Oguejiofor, Philosophy and African Predicament, (Ibadan: Hope Publishers Limited, 2001), p. 97

${ }^{54}$ Ibid.

${ }^{55}$ Ibid.

${ }^{56}$ Ibid.

${ }^{57}$ Ibid.

${ }^{58}$ Quoted by J. Oguejiofor, ibid., Cf. L. Senghor, "Discours devant le Parlement du Ghana", February, 1961, in Prose and Poetry, (London: Heinemann, 1965), p.98

${ }^{59}$ Quoted by J. Oguejiofor, Ibid., Cf. L. Senghor, "Discours devant le Parlement du Ghana", February, 1961, in Prose and Poetry, (London: Heinemann, 1965), p.98

${ }^{60}$ J. Oguejiofor, Loc. Cit., p. 97 - 98

${ }^{61}$ Ibid., p. 98

${ }^{62}$ Ibid.

${ }^{63}$ Ibid.

${ }^{64}$ Ibid.

${ }^{65}$ Quoted by J. Oguejiofor, Ibid. (Ratio is compass, set-square and sextant, measure and weight whereas the logos, before its Aristotelian tempering, before it became diamond, was living speech. - Senghor, Prose and Poetry, p.33).

${ }^{66}$ Ujamaa Cooperative Economics, Retrieved from http:// www.endarkenment.com/kwanzaa/nguzosaba/ujamaa.htm (Access 12/3/2014)

${ }^{67}$ Ibid.

${ }^{68}$ Ibid.

${ }^{69}$ Ibid. 
${ }^{70}$ N. Azikiwe, Ideology for Nigeria: Capitalism, Socialism or Welfarism? (Lagos: Macmillan Nigeria Publishers, Limited, 1979), p.128

${ }^{71}$ J. Omoregbe, Op. Cit., pp. 43-44

${ }^{72}$ N. Azikwe, Loc. Cit., p. 125

${ }^{73}$ J. Omoregbe, Loc.Cit., p.45

${ }^{74}$ Ibid., p. 46

${ }^{75}$ J. Oguejiofor, Op. Cit., p.113

${ }^{76}$ Ibid.

${ }^{77}$ Ibid.

${ }^{78}$ J.Omoregbe, A Simplified History of Western Philosophy: Ancient and Medieval Philosophy, (Lagos: Joja Press, 2009), p.4

${ }^{79} \mathrm{~W}$. Lawhead, The Voyage of Discovery: A Historical Introduction to Philosophy, (Belmont: Wadsworth/Thomson Learning, 2002), p. 360

${ }^{80}$ Quoted by J. Oguejiofor, Op. cit., p. 117

${ }^{81}$ Ibid.

${ }^{82}$ Ibid. 